\section{The primitive squamous cell carcinoma of the third duodenum}

\author{
Azeddine Diffaa, Zouhour Samlani, \\ Youssef Narjis, Khalid Rabani, \\ Taoufik Ablulhassan, Nacer Samkaoui, \\ Benacer Finech, Khadija Krati \\ Gastroenterology Department, Medicine \\ Faculty of Marrakech, Cadi Ayad \\ University, Marrakech, Morocco
}

\section{Abstract}

The duodenum is an exceptional location of the primary squamous cell carcinoma. Few cases have been reported in the literature. We report here the second case of this tumor in this exceptional location (transverse duodenum) in a sixty years-old women without medical history, who consulted for epigastric pain since 3 months, associated with an episode of melena and weight loss of $5 \mathrm{~kg}$. The assessement and pathological study of endoscopic specimen confirms the squamous cell nature of the tumor. The treatment consisted of palliative chemotherapy with analgesic treatment.

\section{Introduction}

The duodenum is an exceptional location of the primary squamous cell carcinoma. Few cases have been reported in the literature. This uncertain entity continues to generate debate about its pathogenesis.

\section{Case Report}

Sixty years-old women without medical history, consulted for epigastric pain since 3 months, associated with an episode of melena and weight loss of $5 \mathrm{~kg}$. Clinical examination noted a good hemodynamic state with an epigastric mass measuring $5 \mathrm{~cm} / 4 \mathrm{~cm}$, fixed. The biologic assessment noted a normal hemoglobin level. The upper digestive endoscopy showed a circumferential budding tumor reducing lumen of the third duodenum (Figure 1). The pathological study of specimens concluded to an infiltrating pure squamous cell carcinoma. The assessment in search of any primary tumor that can metastasize to the duodenum (cavum, larynx, skin, lung, cervix, anus ...) was negative; so a chess $\mathrm{x}$-ray, laryngoscopy, cavoscopy, gynecological examination with vaginal smear, cervical and thoracic CTscan, proctologic examination were normal. An abdominal CT-scan highlighted an epigastric intra-peritoneal mass of $7 \mathrm{~cm} / 6 \mathrm{~cm}$ diameter enhanced by the contrast injection (Figure 2). The mass infiltrated the horizontal part of duodenum and a part of the body of the pancreas with multiple peripancreatic and para-aortic lymph nodes. None pet-scan was performed in this case. The treatment consisted of palliative chemotherapy with analgesic treatment. No palliative endoscopic treatment was required. The patient died one month later.

\section{Discussion}

The primitive squamous cell carcinoma of the duodenum is very rare tumor. ${ }^{1}$ It usually localized in peripapillary area at the second duodenum. ${ }^{1}$ Its location is exceptional in the third duodenum; to our knowledge one case has been described in the literature. ${ }^{1}$ This histopatholigic entity is controversial. It's often composed by three components: adenocarcinoma, squamous cell carcinoma and neuroendocrine carcinoma. ${ }^{1,2}$ Some authors speculated that the tumor in their case had arisen from duodenal pluripotent stem cells capable of differentiating into multiple cell types. ${ }^{3}$ In our case the tumor was a pure squamous cell carcinoma. Some cases of duodenal metastasis have been reported with breast, lung, pancreas, cervix and stomach cancers. ${ }^{4,5}$ So the original character can't be held that after elimination of a extraduodenal primary tumor by the use of clinical and paraclinical investigation (chess $\mathrm{x}$-ray, laryngoscopy, cavoscopy, gynecological examination with vaginal smear, cervical and thoracic CT-scan, proctologic examination ...). ${ }^{4,5}$ The symptoms are not specific: digestive bleeding (hematemesis, melena), epigastric pain, duodenal obstruction and perforation, jaundice. ${ }^{3}$

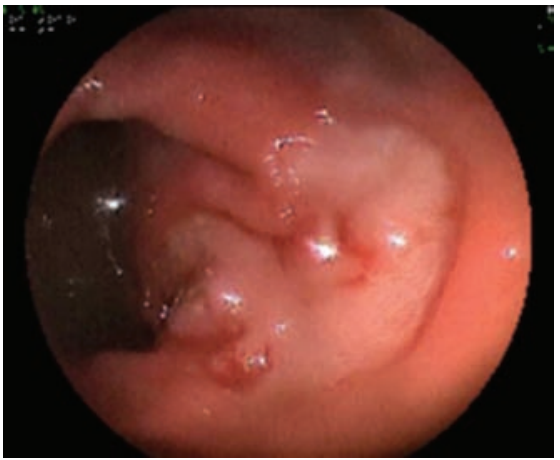

Figure 1. Endoscopic feature of the tumor of the transverse duodenum.

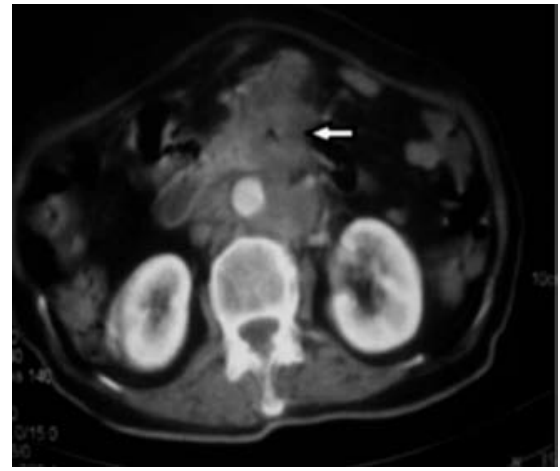

Correspondence: Diffaa Azeddine, Gastroenterology Department, Medicine Faculty of Marrakech, Cadi Ayad University, Marrakech, Morocco. Tel. +212.664477558 .

E-mail drdiffaa@hotmail.fr

Key words: squamous cell, duodenum, cancer, endoscopy.

Received for publication: 20 September 2011 Revision received: 28 February 2012. Accepted for publication: 1 March 2012.

This work is licensed under a Creative Commons Attribution NonCommercial 3.0 License (CC BYNC 3.0).

(C) Copyright A. Diffaa et al., 2012

Licensee PAGEPress, Italy

Gastroenterology Insights 2012; 4:e7

doi:10.4081/gi.2012.e7

It depends on the seat of the tumor and invasion (bile ducts and duodenal wall). ${ }^{3}$ In this case the epigastric pain and weight loss were the two symptoms that the patient present. The endoscopic pattern is variable: mucosa coloration abnormalities, budding mass, necrotic ulcers, and multiple mucosal nodules. ${ }^{3}$ The electronic chromoendoscopy or by Lugol solution could be helpful for diagnosis of early stage as in the oesophagus..$^{5}$ The imaging by CT-scan or RMN is very helpful for extension assessment and the search of extraduodenal primitive tumor. ${ }^{2}$ To our knowledge no papers about the utility of the PET-scan in this location has been published yet. in another location (anus, esophagus...) it allows staging of the tumor. ${ }^{6}$ The treatment consists of surgery if the lesion is resectable. ${ }^{1}$ The prognosis in cases such as this is very difficult to determine.

Figure 2. Abdominal computed tomography-scan highlighted a transverse duodenum tumor that invade pancreas with periaortic lymph nodes. 


\section{Conclusions}

The duodenal location of a primitive squamous cell carcinoma is exceptional. Duodenal metastasis has been reported. Gastrointestinal endoscopy plays an important role in the diagnosis.

\section{References}

1. Friedmen E, Kwan MR, Cummins L.
Squamous cell of the transverse duodenum Gastrointest Endosc 1986;32:99-101.

2. Terada T. Primary pure squamous cell carcinoma of the duodenum: report of three cases. Endoscopy 2009;41:E329-30.

3. Barnhill M, Hess E, Guccion JG, et al. Tripartite differentiation in a carcinoma of the duodenum. Cancer 1994;73:266-72.

4. Metges JP, Labat JP, Giroux MA, et al. Métastases gastro duodénales: mode de révélation exceptionnel du cancer du poumon: étude de deux cas et revue de litérature. Rev Med Intern 2001;22:465-8.

5. Raphael JC, Ram TS, Pavamani S, et al.
Squamous cell carcinoma cervix with metastasis to pyloroduodenal region. J Cancer Res Ther 2011;7:183-4.

6. Nagle D, Henry D, Iagaru A, et al. The utility of PET scanning in the management of squamous cell carcinoma of the anus. J Clin Oncol 2006 ASCO Annual Meeting Proceedings Part I. Vol 24, No. 18S (June 20 Supplement), 2006: 4152. Available from: http://www.asco.org/ ascov2/ Meetings/Abstracts?\&vmview= abst_detail_view\&confID $=40 \&$ abstractID $=34703$ 